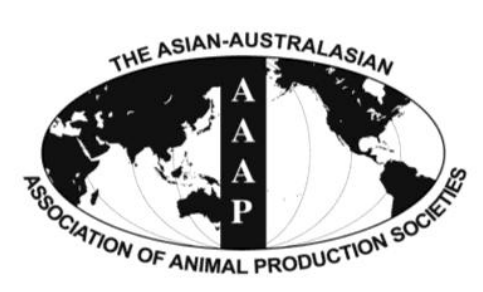

\title{
The Effects of Fat-soluble Vitamin Administration on Plasma Vitamin Status of Nursing Pigs Differ When Provided by Oral Administration or Injection
}

\author{
Y. D. Jang, M. D. Lindemann*, H. J. Monegue, and R. L. Stuart ${ }^{1}$ \\ Department of Animal and Food Sciences, University of Kentucky, Lexington KY 40546, USA
}

\begin{abstract}
Four experiments were conducted to investigate the effect of fat-soluble vitamin administration to sows or newborn pigs on plasma vitamin status. In Exp. 1 and 2, a total of 24 and 43 newborn pigs were allotted to control and vitamin treatments (vitamin $\mathrm{D}_{3}$ with variable addition of vitamins A and E) orally or by i.m. injection. In Exp. 3, pigs from Exp. 2 were allotted to 2 treatments ( \pm vitamins $\mathrm{D}_{3}$ and $\mathrm{E}$ in drinking water) for $14 \mathrm{~d}$ postweaning. In Exp. 4, twenty-four gestating sows were used for 2 treatments ( \pm injection of a vitamin $\mathrm{D}_{3} / \mathrm{A} / \mathrm{E}$ product $2 \mathrm{wk}$ prepartum). In Exp. 1 and 2 , when vitamin $\mathrm{D}_{3}$ was administrated orally or by i.m. injection on $\mathrm{d} 1$ of age, pigs had increased plasma 25-hydroxycholecalciferol (25-OH $\left.\mathrm{D}_{3}\right)$ concentration $10 \mathrm{~d}$ after administration compared with control pigs $(\mathrm{p}<0.05)$. The injectable administration with vitamin $\mathrm{D}_{3}$ and $\mathrm{E}$ was able to achieve higher plasma $25-\mathrm{OH} \mathrm{D}_{3}$ $(\mathrm{p}<0.05)$ and $\alpha$-tocopherol $(\mathrm{p}<0.05)$ concentrations than oral administration. At weaning, the pigs in the injection group had higher plasma $25-\mathrm{OH} \mathrm{D}_{3}$ concentration than those in the other groups in both studies $(\mathrm{p}<0.05)$. In Exp. 3, water supplementation of vitamin $\mathrm{D}_{3}$ and $\mathrm{E}$ postweaning increased plasma $25-\mathrm{OH} \mathrm{D}_{3}$ and $\alpha$-tocopherol concentrations at $\mathrm{d} 14$ postweaning $(\mathrm{p}<0.01)$. In Exp. 4 , when sows were injected with the vitamin $\mathrm{D}_{3}$ product prepartum, serum $25-\mathrm{OH} \mathrm{D}_{3}$ concentrations of sows at farrowing $(\mathrm{p}<0.01)$, and in their progeny at birth $(\mathrm{p}<0.01)$ and weaning $(\mathrm{p}<0.05)$ were increased. These results demonstrated that fat-soluble vitamin administration to newborn pigs increased plasma $25-\mathrm{OH} \mathrm{D}_{3}$ concentration regardless of administration routes and $\alpha$-tocopherol concentration by the injectable route, and that water supplementation of vitamin $\mathrm{D}_{3}$ and $\mathrm{E}$ to nursery pigs increased plasma $25-\mathrm{OH} \mathrm{D}_{3}$ and $\alpha$-tocopherol concentrations. Additionally, injecting sows with vitamin $\mathrm{D}_{3}$ prepartum increased $25-\mathrm{OH}_{3}$ in sows and their offspring. If continued research demonstrates that the serum levels of $25-\mathrm{OH} \mathrm{D}_{3}$ are critical in weanling pigs, a variety of means to increase those levels are available to swine producers. (Key Words: Fat-soluble Vitamin, Piglets, Sows, Administration Routes, Vitamin $\mathrm{D}_{3}$ )
\end{abstract}

\section{INTRODUCTION}

Vitamin D has not been a major issue in the swine industry for several decades but in the past few years, attention on vitamin $\mathrm{D}$ and its status in pigs has risen with the increasing occurrence of metabolic bone diseases in some production settings (Madson et al., 2012). Recently, seemingly low concentrations of plasma vitamin D have been identified in periweaning failure to thrive syndrome

\footnotetext{
* Corresponding Author: M. D. Lindemann. Tel: +1-859-2577524, Fax: +1-859-323-1027, E-mail: merlin.lindemann@uky.edu ${ }^{1}$ Stuart Products Inc., Bedford TX 76022, USA.

Submitted Dec. 7, 2013; Revised Jan. 10, 2014; Accepted Mar. 8, 2014
}

(PFTS), noted by veterinarians and researchers since 2008 (Huang et al., 2011). Consequently, products are available in the US as a means to specifically modify the plasma vitamin D levels in an attempt to prevent pigs from developing metabolic bone diseases and the mortality associated with PFTS. Some of the products contain only vitamin $\mathrm{D}$ while other products are a combination of fatsoluble vitamins.

Several recent studies have been conducted to investigate vitamin $\mathrm{D}$ requirements and/or supplementation/administration to sows and piglets (Lauridsen et al., 2010; Witschi et al., 2011; Rortvedt et al., 2012; Flohr et al., 2014a). The supplementation of vitamin D to gestation and lactation diets at concentrations above 
NRC (1998) requirement was demonstrated to increase serum vitamin D concentration of sows (Lauridsen et al., 2010) and their progeny (Witschi et al., 2011). Regarding vitamin $\mathrm{D}$ supplementation to piglets, when newborn pigs were supplemented with vitamin $\mathrm{D}_{3}$ via oral administration at 40,000 or $80,000 \mathrm{IU}$ of vitamin $\mathrm{D}_{3}$, higher serum 25-hydroxycholecalciferol $\left(25-\mathrm{OH} \mathrm{D}_{3}\right)$ concentration was detected at weaning compared with pigs without vitamin $\mathrm{D}_{3}$ administration (Flohr et al., 2014a). On the other hand, Goff et al. (1984) suggested that the parenteral vitamin $D_{3}$ treatment to sows at d 20 prepartum by i.m. injection of vitamin $D_{3}$ was an effective method for enhancing vitamin D status of newborn piglets because the vitamin D status of sows was closely correlated to that of the fetus and neonatal piglets. Based on these limited results, an increased serum vitamin $\mathrm{D}$ concentration of piglets seems to be possible via several methods such as oral administration to piglets, supplementation to maternal feed and injection to sows. However, the relationship of that increased serum concentration to increased performance or bone measure is not always present. Regarding other fat soluble vitamins, vitamin E injection of $300 \mathrm{IU}$ to neonatal pigs has been demonstrated to increase plasma $\alpha$-tocopherol levels on $1 \mathrm{~d}$ after injection (Hill et al., 1999), and Håkansson et al. (2001) reported that plasma retinol concentration of suckling piglets were influenced by the vitamin A status of sows and colostrum. However, limited information is available for a direct comparison of fat-soluble vitamin administration to newborn pigs by different administration routes. Therefore, the objective of the current research was to evaluate the effects of a variety of supplemental fatsoluble vitamin products administered by different administration routes to young pigs as well as the efficacy of vitamin $\mathrm{D}_{3}$ injection to sows prepartum.

\section{MATERIALS AND METHODS}

All procedures in this study were conducted in accordance with guidelines stated in the Guide for the Care and Use of Agricultural Animals in Agricultural Research and Teaching by the Federation of Animal Science Societies (FASS, 2010).

\section{Animals and experimental design}

Exp. 1: A total of 24 pigs (Yorkshire $\times$ Duroc) were used from 4 litters (i.e., 6 pigs/sow; average parity: 4.0). At birth, pigs were assigned to 3 treatments within each litter based on gender and body weight $(\mathrm{BW})$ in a randomized complete block design (RCBD). Treatments were: i) control: no supplemental vitamin, ii) i.m. injection of $0.8 \mathrm{~mL}$ of a vitamin complex (VITAL E-NEWBORN containing $500 \mathrm{IU}$ of vitamin $E$ as d- $\alpha$-tocopherol, 50,000 IU of vitamin $A$ as retinyl palmitate, and 50,000 IU of vitamin $\mathrm{D}_{3}$ per $\mathrm{mL}$ ), and iii) oral administration of $0.8 \mathrm{~mL}$ of a vitamin complex (EMCELLE NEWBORN EAD containing 500 IU of vitamin $\mathrm{E}$ as $\mathrm{d}$ - $\alpha$-tocopherol, 50,000 IU of vitamin $\mathrm{A}$ as retinyl palmitate, and 50,000 IU of vitamin $\mathrm{D}_{3}$ per $\mathrm{mL}$ ). The commercial products used were from Stuart Products Inc. (Bedford Texas, USA).

Exp. 2: This experiment was conducted to verify the effect of various combinations of oral fat-soluble vitamin product administration with control and injectable administration. A total of 43 pigs (Yorkshire $\times$ Duroc) were used from 4 litters (average parity: 4.8). At birth, a pig was assigned to each of 6 treatments within each litter in a completely randomized design (CRD); and, following the initial assignment of pigs, any remaining pigs in each litter were allotted to treatments 1 and 2 . Treatments were: i) control: no supplemental vitamin, ii) i.m. injection of 1.00 $\mathrm{mL}$ of a vitamin complex (VITAL E-NEWBORN containing $500 \mathrm{IU}$ of vitamin $\mathrm{E}$ as d- $\alpha$-tocopherol, 50,000 IU of vitamin A as retinyl palmitate, and 50,000 IU of vitamin $\mathrm{D}_{3}$ per $\mathrm{mL}$ ), iii) oral administration of $1.00 \mathrm{~mL}$ of a vitamin complex (EMCELLE NEWBORN EAD containing $500 \mathrm{IU}$ of vitamin $\mathrm{E}$ as d- $\alpha$-tocopherol, 50,000 IU of vitamin A as retinyl palmitate, and 50,000 IU of vitamin $\mathrm{D}_{3}$ per $\mathrm{mL}$ ), iv) oral administration of $1.66 \mathrm{~mL}$ of a vitamin $\mathrm{D}$ and E complex (EMCELLE ED3 containing 30,000 IU of vitamin $\mathrm{D}_{3}$ and 500 IU of vitamin $\mathrm{E}$ as $\mathrm{d}$ - $\alpha$-tocopherol per $\mathrm{mL}$ ), v) oral administration of $0.60 \mathrm{~mL}$ of vitamin $\mathrm{D}_{3}$ (EMCELLE D3 containing 84,500 IU of vitamin $\mathrm{D}_{3}$ per $\mathrm{mL}$ ), and vi) oral administration of $1.66 \mathrm{~mL}$ of vitamin $\mathrm{E}$ (EMCELLE E containing 500 IU of vitamin $E$ as $d-\alpha-$ tocopherol per $\mathrm{mL}$ ). The products used were from Stuart Products Inc. (Bedford Texas, USA).

Exp. 3: All piglets from Exp. 2 were allotted to 1 of 2 additional treatments at weaning in a split plot design. With a main plot from the treatments at birth in Exp. 2, a subplot was divided into a control group without a vitamin product in drinking water and a group that consumed drinking water with a vitamin $\mathrm{D}_{3}$ and $\mathrm{E}$ product (EMCELLE ED3-LIQUID, Stuart Products Inc., Bedford, Texas, USA) containing $30,000 \mathrm{IU}$ of vitamin $\mathrm{D}_{3}$ and $500 \mathrm{IU}$ of vitamin $\mathrm{E}$ as $\mathrm{d}-\alpha-$ tocopherol per $\mathrm{mL}$ during the first $14 \mathrm{~d}$ after weaning. The product was proportioned into the water at a rate that provided drinking water that contained 5,658 IU of vitamin $\mathrm{D}_{3}$ and $95 \mathrm{IU}$ of vitamin $\mathrm{E}$ per L.

Exp. 4: A total of 24 sows (Pig Improvement Company; average parity: 5.2) were allotted to 2 treatments in a CRD. Treatments were divided into a control group without injection and a group that received a $5 \mathrm{~mL}$ injection at $2 \mathrm{wk}$ prepartum of a vitamin $\mathrm{D}_{3}$ product (VITAL E-Hi $\mathrm{A}+\mathrm{D}$, Stuart Products Inc., Bedford, Texas, USA) containing 100,000 IU of vitamin $D_{3}, 300$ IU of vitamin $E$ as $d-\alpha-$ tocopherol, and 200,000 IU of vitamin A as retinyl 
palmitate per $\mathrm{mL}$.

\section{Diets, housing and sample collection}

Exp. 1 and 2: All sows with pigs were kept in individual farrowing crates in an environmentally controlled farrowing facility without windows. In Exp. 1, the lactation diet for sows was a corn-soybean meal (SBM)-based diet. In Exp. 2, the lactation diets for sows were corn-SBM-based diets with $10 \%$ distillers dried grains with solubles (DDGS). In both experiments, the gestation and lactation diets contained the following per kg diet: vitamin A, 6,600 IU; vitamin $\mathrm{D}_{3}$, $880 \mathrm{IU}$; vitamin E, $44 \mathrm{IU}$; vitamin $\mathrm{K}$ (menadione sodium bisulfite complex), $6.6 \mathrm{mg}$; riboflavin, $8.8 \mathrm{mg}$; d-pantothenic acid, $22 \mathrm{mg}$; niacin, $44 \mathrm{mg}$; vitamin $\mathrm{B}_{6}, 4.4 \mathrm{mg}$; vitamin $\mathrm{B}_{12}$, $33 \mu \mathrm{g}$; d-biotin, $220 \mu \mathrm{g}$; and folic acid, $1.32 \mathrm{mg}$. Sows were provided 1.8 to $2.5 \mathrm{~kg}$ of the gestation diet before being brought to the farrowing rooms at about d 112 of gestation. Sows were provided the lactation diet ad libitum and water was freely available from a water nipple throughout the experimental period. All pigs were processed at birth (within $15 \mathrm{~h}$ ) and assigned to a treatment. Processing of the piglets involved weighing, ear-notching, needle teeth clipping, and iron injection with $100 \mathrm{mg}$ as Fe-dextran. With regard to administration of treatments, pigs were administered vitamin products by either injection or oral placement in the back of the mouth. Injectable products were provided to each pig in the trapezius muscle on the opposite side of the neck where the iron injection was given. Orally administered treatments were provided through a plastic tube attached to a $3 \mathrm{~mL}$ syringe into which the proper dosage had been drawn. The $\mathrm{BW}$ of the pigs were also recorded about $10 \mathrm{~d}$ after administration (average 11.75 d of age, $12 \pm 1 \mathrm{~d}$ for Exp. 1; average $12.00 \mathrm{~d}$ of age, $12 \pm 1 \mathrm{~d}$ for Exp. 2) and weaning (19.50 d of age, $20 \pm 1 \mathrm{~d}$ for Exp. 1; $20.25 \mathrm{~d}$ of age, $20 \pm 1 \mathrm{~d}$ for Exp. 2) to calculate growth performance. In addition, the $\mathrm{BW}$ of sows was obtained at farrowing and weaning.

Blood samples of sows were taken into heparincontaining tubes from the anterior vena cava at farrowing and weaning. Blood samples of pigs were collected from the anterior vena cava on d 0 or 1 (before administration of any treatments), approximately $10 \mathrm{~d}$ after administration of treatments and weaning. Blood samples were centrifuged at $1,700 \mathrm{~g}$ for $15 \mathrm{~min}$ at $4^{\circ} \mathrm{C}$; plasma samples were then aliquoted into microtubes and stored at $-20^{\circ} \mathrm{C}$ until analysis. Plasma samples were sent to the Iowa State University Veterinary Diagnostic Laboratory for vitamin assay (Ames IA, USA).

Exp. 3: Five to seven pigs were housed per $1.22 \times 1.22$ $\mathrm{m}^{2}$ raised-deck nursery pen with plastic coated expanded metal flooring. The diet provided was a $1.21 \%$ standardized ileal digestible lysine corn-SBM-based starter diet that contained the following per $\mathrm{kg}$ diet: vitamin A, 4,950 IU; vitamin $\mathrm{D}_{3}, 660 \mathrm{IU}$; vitamin $\mathrm{E}, 33 \mathrm{IU}$; vitamin $\mathrm{K}$ (menadione sodium bisulfite complex), $4.95 \mathrm{mg}$; riboflavin, $6.6 \mathrm{mg}$; d-pantothenic acid, $16.5 \mathrm{mg}$; niacin, $33 \mathrm{mg}$; vitamin $\mathrm{B}_{6}, 3.3 \mathrm{mg}$; vitamin $\mathrm{B}_{12}, 24.75 \mu \mathrm{g}$; d-biotin, $165 \mu \mathrm{g}$; and folic acid, $990 \mu \mathrm{g}$.

Blood samples of pigs were collected from the anterior vena cava at d 14 postweaning. Blood samples were centrifuged at $1,700 \mathrm{~g}$ for $15 \mathrm{~min}$ at $4^{\circ} \mathrm{C}$, aliquoted into microtubes and stored at $-20^{\circ} \mathrm{C}$ until analysis. Plasma samples were sent to the Iowa State University Veterinary Diagnostic Laboratory for vitamin assay. Blood data at weaning from Exp. 2 were used as the initial values in Exp. 3.

Exp. 4: All sows with pigs were housed in individual farrowing crates in an environmentally controlled farrowing facility. The sows were provided a common gestation diet containing 2,750 IU/kg of vitamin $\mathrm{D}_{3}$, as well as a common lactation diet that also contained $2,750 \mathrm{IU} / \mathrm{kg}$ of vitamin $\mathrm{D}_{3}$. The gestation diet was a corn-SBM-based diet with $60 \%$ DDGS and phytase (750 FTU/kg; Phyzyme XP 10000, Danisco Animal Nutrition, Marlborough, UK) and the lactation diet was a corn-SBM-based diet with $20 \%$ DDGS and phytase (750 FTU/kg; Phyzyme XP 10000, Danisco Animal Nutrition). Water was freely available throughout the experimental period.

The injectable product was administered into a neck muscle and sows were bled immediately preceding administration of the product and again at parturition. Two piglets were selected from each litter at birth for blood sampling; one of the two selected piglets was bled again at weaning. Blood samples were centrifuged; serum samples were put into microtubes and submitted to the Iowa State University Veterinary Diagnostic Laboratory for analysis of 25- $\mathrm{OH} \mathrm{D} \mathrm{D}_{3}$ concentrations.

\section{Statistical analysis}

Data from Exp. 1 were analyzed by ANOVA for a RCBD using MIXED procedure of SAS (SAS Inst. Inc., Cary, NC, USA). Fixed effect was the vitamin treatment and random effects were the litter, gender and gender $\times$ treatment interaction. Data from Exp. 2 were analyzed by ANOVA for a CRD using MIXED procedure of SAS. Fixed effect was solely the vitamin treatment. Data of plasma vitamin levels of sows between farrowing and weaning were analyzed by ANOVA using MIXED procedure of SAS containing the day (farrowing and weaning) as a fixed effect and the sow as a random effect. In Exp. 3, pigs from treatments 1 and 2 from Exp. 2 were used for statistical analysis whereas treatments 3 to 6 from Exp. 2 were not used in the analysis because of inadequate replication and imbalance among treatments. Data from Exp. 3 were analyzed by ANOVA for a spilt plot design using MIXED 
procedure of SAS. Main plot was lactation treatment and subplot was nursery water treatment. Models included lactation treatment, nursery water treatment, and their interaction as fixed effects, and the pig within lactation treatment as a random effect. Data from Exp. 4 were analyzed by ANOVA for a CRD using MIXED procedure of SAS. Fixed effect was solely the vitamin treatment. Individual pig and sow were considered the experimental units. Least squares means were separated using PDIFF option in SAS. Statistical differences were considered significant at $\mathrm{p}<0.05$, and a trend at $\mathrm{p}<0.10$.

\section{RESULTS}

The effect of vitamin $\mathrm{D}_{3}$ supplementation with vitamins $A$ and $E$ to newborn pigs in Exp. 1 on plasma $25-\mathrm{OH} D_{3}$, retinol, and $\alpha$-tocopherol concentrations is shown in Table 1. At $10 \mathrm{~d}$ after administration all groups treated with a vitamin $\mathrm{D}_{3}$ product had higher plasma 25-OH $\mathrm{D}_{3}$ concentration than the control group $(\mathrm{p}<0.05)$. Additionally, when the pigs received the injectable product, the plasma $25-\mathrm{OH} \mathrm{D}_{3}$ concentration was the highest among treatments $(\mathrm{p}<0.05)$. At weaning, plasma values for injection and oral treatments declined from $10 \mathrm{~d}$ after administration but plasma values for the injection treatment remained elevated relative to plasma values for the other pigs $(\mathrm{p}<0.05)$. With regard to plasma retinol and $\alpha$-tocopherol concentrations, there were no differences except at $10 \mathrm{~d}$ after administration when plasma $\alpha$-tocopherol concentrations of pigs in the injection group were the highest among all treatments $(\mathrm{p}<0.05)$ and tended to be maintained until weaning $(\mathrm{p}=$ 0.09).

In Exp. 2 (Table 2), the effect of vitamin $\mathrm{D}_{3}$ and variable vitamin $\mathrm{A}$ and $\mathrm{E}$ administration to newborn pigs on plasma 25-OH $\mathrm{D}_{3}$ concentrations demonstrates again that the plasma concentrations at $10 \mathrm{~d}$ after administration can be increased by either oral or injectable administration $(p<0.05)$, that values decline from $10 \mathrm{~d}$ after administration to weaning regardless of treatment, and that values at weaning can remain higher than those of control pigs in which no treatment was administered $(\mathrm{p}<0.05)$. The injectable product resulted in the highest plasma values and the results were higher than the oral administration treatments at weaning $(\mathrm{p}<0.05)$. In the case of $\alpha$-tocopherol, the vitamin $\mathrm{E}$ injection to piglets was also more effective to increase plasma $\alpha$-tocopherol concentration at $10 \mathrm{~d}$ after administration compared with the oral administration $(p<0.05)$. However, at weaning the highest numerical value was actually from one of the oral products that contained vitamin $\mathrm{E}$ and it, as well as the injectable product, was higher than that of the control pigs $(\mathrm{p}<0.05)$. Plasma $25-\mathrm{OH}$ $\mathrm{D}_{3}$ levels of sows were higher at weaning than farrowing in both Exp. 1 and $2(\mathrm{p}<0.05)$.

The effects of the treatments on BW and growth in Exp. 1 and 2 are provided in Table 3 and 4. No differences among treatments were detected on $\mathrm{BW}$ and average daily gain (ADG) of pigs during suckling periods in either experiment.

The effect of vitamins $\mathrm{D}_{3}$ and $\mathrm{E}$ supplementation via drinking water to nursery pigs in Exp. 3 is presented in

Table 1. Effect of fat-soluble vitamin administration to pigs on plasma 25 -hydroxycholecalciferol $\left(25-\mathrm{OH} \mathrm{D}_{3}\right)$, retinol, and $\alpha$-tocopherol concentration (Exp. 1) $)^{1,2}$

\begin{tabular}{|c|c|c|c|c|c|c|}
\hline \multirow{2}{*}{ Criteria } & \multirow{2}{*}{$\begin{array}{c}\text { Sow } \\
(\mathrm{n}=4)\end{array}$} & \multicolumn{3}{|c|}{ Treatments $^{3}$} & \multirow{2}{*}{ SEM } & \multirow{2}{*}{ p-values } \\
\hline & & Control & Inj. vit. $\mathrm{A}, \mathrm{D}_{3}, \mathrm{E}$ & Oral vit. $\mathrm{A}, \mathrm{D}_{3}, \mathrm{E}$ & & \\
\hline \multicolumn{7}{|c|}{$25-\mathrm{OH} \mathrm{D}_{3}(\mathrm{ng} / \mathrm{mL})$} \\
\hline Initial & $21.23^{4}$ & 2.58 & 2.68 & 2.65 & 0.18 & 0.92 \\
\hline d 10 & & $5.87^{\mathrm{c}}$ & $82.61^{\mathrm{a}}$ & $38.49^{\mathrm{b}}$ & 3.33 & $<0.01$ \\
\hline Weaning & 31.60 & $5.88^{\mathrm{b}}$ & $30.53^{\mathrm{a}}$ & $10.01^{\mathrm{b}}$ & 3.26 & 0.04 \\
\hline \multicolumn{7}{|c|}{ Retinol $(\mu \mathrm{g} / \mathrm{mL})$} \\
\hline Initial & & 0.16 & 0.13 & 0.14 & 0.02 & 0.50 \\
\hline d 10 & & 0.37 & 0.37 & 0.28 & 0.05 & 0.32 \\
\hline Weaning & & 0.35 & 0.20 & 0.19 & 0.08 & 0.16 \\
\hline \multicolumn{7}{|c|}{$\alpha$-Tocopherol ( $\mu \mathrm{g} / \mathrm{mL})$} \\
\hline Initial & & 2.25 & 1.83 & 1.83 & 0.35 & 0.62 \\
\hline d 10 & & $6.85^{\mathrm{b}}$ & $15.20^{\mathrm{a}}$ & $3.75^{\mathrm{b}}$ & 1.91 & 0.01 \\
\hline Weaning & & 3.93 & 5.93 & 3.62 & 0.93 & 0.09 \\
\hline
\end{tabular}


Table 2. Effect of fat-soluble vitamin administration to pigs on plasma 25 -hydroxycholecalciferol (25-OH $\left.\mathrm{D}_{3}\right)$, retinol, and $\alpha$-tocopherol concentration (Exp. 2) $)^{1,2}$

\begin{tabular}{|c|c|c|c|c|c|c|c|c|c|}
\hline \multirow[b]{2}{*}{ Criteria } & \multirow{2}{*}{$\begin{array}{c}\text { Sow } \\
(\mathrm{n}=4)\end{array}$} & \multicolumn{6}{|c|}{ Treatment $^{3}$} & \multirow[b]{2}{*}{ SEM } & \multirow[b]{2}{*}{ p-values } \\
\hline & & Control & $\begin{array}{c}\text { Inj. } \\
\mathrm{A}, \mathrm{D}_{3}, \mathrm{E}\end{array}$ & $\begin{array}{c}\text { Oral } \\
A, D_{3}, E\end{array}$ & $\begin{array}{c}\text { Oral } \\
D_{3}, E\end{array}$ & $\begin{array}{c}\text { Oral } \\
\mathrm{D}_{3}\end{array}$ & $\begin{array}{c}\text { Oral } \\
\text { E }\end{array}$ & & \\
\hline \multicolumn{10}{|c|}{$\overline{25-\mathrm{OH} \mathrm{D}} \mathrm{D}_{3}(\mathrm{ng} / \mathrm{mL})$} \\
\hline Initial & $26.45^{4}$ & 4.41 & 4.47 & 4.40 & 5.45 & 4.38 & 5.10 & 0.82 & 0.93 \\
\hline d 10 & & $8.25^{\mathrm{b}}$ & $110.74^{\mathrm{a}}$ & $77.17^{\mathrm{a}}$ & $84.68^{\mathrm{a}}$ & $86.20^{\mathrm{a}}$ & $6.47^{\mathrm{b}}$ & 15.28 & $<0.001$ \\
\hline Weaning & 32.65 & $5.02^{\mathrm{c}}$ & $40.24^{\mathrm{a}}$ & $26.10^{\mathrm{b}}$ & $27.30^{\mathrm{b}}$ & $30.88^{\mathrm{b}}$ & $5.10^{\mathrm{c}}$ & 3.13 & $<0.001$ \\
\hline \multicolumn{10}{|c|}{ Retinol $(\mu \mathrm{g} / \mathrm{mL})$} \\
\hline Initial & 0.16 & 0.04 & 0.07 & 0.11 & 0.08 & 0.10 & 0.10 & 0.02 & 0.21 \\
\hline d 10 & & 0.23 & 0.25 & 0.25 & 0.21 & 0.26 & 0.28 & 0.03 & 0.69 \\
\hline Weaning & 0.27 & 0.18 & 0.16 & 0.17 & 0.16 & 0.11 & 0.18 & 0.05 & 0.92 \\
\hline \multicolumn{10}{|c|}{$\alpha$-Tocopherol $(\mu \mathrm{g} / \mathrm{mL})$} \\
\hline Initial & $1.23^{4}$ & 3.24 & 2.86 & 3.68 & 4.30 & 2.70 & 1.43 & 1.38 & 0.88 \\
\hline $\mathrm{d} 10$ & & $4.78^{\mathrm{b}}$ & $11.26^{\mathrm{a}}$ & $5.37^{\mathrm{b}}$ & $6.93^{\mathrm{ab}}$ & $4.80^{\mathrm{b}}$ & $5.80^{\mathrm{b}}$ & 1.59 & $<0.01$ \\
\hline Weaning & 3.13 & $4.51^{\mathrm{b}}$ & $7.16^{\mathrm{a}}$ & $5.93^{\mathrm{ab}}$ & $7.33^{\mathrm{a}}$ & $3.85^{\mathrm{b}}$ & $4.80^{\mathrm{ab}}$ & 0.84 & $<0.01$ \\
\hline
\end{tabular}

SEM, standard error of the mean.

${ }^{1} 43$ pigs were used for all analysis $\left(n=14,13,4,4,4\right.$, and 4 for control, Inj. A, $\mathrm{D}_{3}, \mathrm{E}$; Oral A, $\mathrm{D}_{3}, \mathrm{E}$; Oral $\mathrm{D}_{3}, \mathrm{E} ;$ Oral $\mathrm{D}_{3}$; Oral E).

${ }^{2}$ Initial, d 0 or 1 of age before administration of treatments; d 10, $10 \mathrm{~d}$ after administration (average $12.00 \mathrm{~d}$ of age); weaning, average $20.25 \mathrm{~d}$ of age.

${ }^{3}$ See text for more complete description of treatments.

${ }^{4}$ There were differences in $25-\mathrm{OH} \mathrm{D}_{3}$ and $\alpha$-tocopherol levels of sows between farrowing and weaning (p<0.05; SEM: 2.96, 0.07, and 0.16 for 25-OH $\mathrm{D}_{3}$, retinol and $\alpha$-tocopherol, respectively).

${ }^{\mathrm{a}, \mathrm{b}, \mathrm{c}}$ Means in the same row without a common superscript differ $(\mathrm{p}<0.05)$.

Table 3. Effect of fat-soluble vitamin administration to pigs on growth performance (Exp. 1) $)^{1,2}$

\begin{tabular}{|c|c|c|c|c|c|c|}
\hline \multirow{2}{*}{ Criteria } & \multirow{2}{*}{$\begin{array}{c}\text { Sow } \\
(\mathrm{n}=4)\end{array}$} & \multicolumn{3}{|c|}{ Treatment $^{3}$} & \multirow{2}{*}{ SEM } & \multirow{2}{*}{ p-values } \\
\hline & & Control & Inj. vit. $\mathrm{A}, \mathrm{D}_{3}, \mathrm{E}$ & Oral vit. $\mathrm{A}, \mathrm{D}_{3}, \mathrm{E}$ & & \\
\hline \multicolumn{7}{|l|}{$\overline{\mathrm{BW}}(\mathrm{kg})$} \\
\hline Initial & 231.03 & 1.73 & 1.58 & 1.53 & 0.18 & 0.43 \\
\hline d 10 & & 4.21 & 3.99 & 4.06 & 0.37 & 0.87 \\
\hline Weaning & 242.02 & 6.34 & 5.98 & 6.20 & 0.53 & 0.86 \\
\hline \multicolumn{7}{|l|}{$\mathrm{ADG}(\mathrm{kg} / \mathrm{d})$} \\
\hline Initial to $\mathrm{d} 10$ & & 0.21 & 0.20 & 0.21 & 0.02 & 0.92 \\
\hline d 10 to weaning & & 0.27 & 0.26 & 0.28 & 0.02 & 0.76 \\
\hline Initial to weaning & & 0.24 & 0.22 & 0.24 & 0.02 & 0.88 \\
\hline
\end{tabular}

SEM, standard error of the mean; BW, body weight; ADG, average daily gain.

${ }^{1} 24$ pigs were used ( $\mathrm{n}=8$ for each treatment).

${ }^{2}$ Initial, d 0 or 1 of age before administration of treatments; d 10, $10 \mathrm{~d}$ after administration (average $11.75 \mathrm{~d}$ of age); weaning, average $19.50 \mathrm{~d}$ of age.

${ }^{3}$ The injectable and oral products supplied $400 \mathrm{IU}$ vitamin E, 40,000 IU vitamin A, and 40,000 IU vitamin $\mathrm{D}_{3}$ and were administered on d 1 of life.

Table 4. Effect of fat-soluble vitamin administration to pigs on growth performance (Exp. 2$)^{1,2}$

\begin{tabular}{|c|c|c|c|c|c|c|c|c|c|}
\hline \multirow[b]{2}{*}{ Criteria } & \multirow[b]{2}{*}{ Sow } & \multicolumn{6}{|c|}{ Treatment $^{3}$} & \multirow[b]{2}{*}{ SEM } & \multirow[b]{2}{*}{ p-values } \\
\hline & & Control & $\begin{array}{c}\text { Inj. } \\
A, D_{3}, E\end{array}$ & $\begin{array}{c}\text { Oral } \\
\mathrm{A}, \mathrm{D}_{3}, \mathrm{E}\end{array}$ & $\begin{array}{c}\text { Oral } \\
D_{3}, E\end{array}$ & $\begin{array}{c}\text { Oral } \\
\mathrm{D}_{3}\end{array}$ & $\begin{array}{c}\text { Oral } \\
E\end{array}$ & & \\
\hline \multicolumn{10}{|l|}{ BW (kg) } \\
\hline Initial & 229.5 & 1.56 & 1.55 & 1.51 & 1.60 & 1.58 & 1.83 & 0.17 & 0.86 \\
\hline d 10 & & 3.51 & 3.27 & 3.84 & 3.05 & 3.87 & 4.37 & 0.45 & 0.47 \\
\hline Weaning & 248.2 & 5.53 & 5.12 & 5.84 & 4.12 & 6.44 & 6.90 & 0.72 & 0.24 \\
\hline \multicolumn{10}{|l|}{$\mathrm{ADG}(\mathrm{kg} / \mathrm{d})$} \\
\hline Initial to $\mathrm{d} 10$ & & 0.17 & 0.16 & 0.19 & 0.14 & 0.21 & 0.24 & 0.03 & 0.31 \\
\hline d 10 to weaning & & 0.25 & 0.23 & 0.25 & 0.14 & 0.31 & 0.28 & 0.04 & 0.22 \\
\hline Initial to weaning & & 0.20 & 0.19 & 0.21 & 0.14 & 0.25 & 0.26 & 0.03 & 0.25 \\
\hline
\end{tabular}

SEM, standard error of the mean; BW, body weight; ADG, average daily gain.

${ }^{1} 43$ pigs were used for all analysis $\left(\mathrm{n}=14,13,4,4,4\right.$, and 4 for control, Inj. A, $\mathrm{D}_{3}$, E; Oral A, $\mathrm{D}_{3}$, E; Oral $\mathrm{D}_{3}$, E; Oral $\mathrm{D}_{3}$; Oral E).

${ }^{2}$ Initial, d 0 or 1 of age before administration of treatments; d 10, $10 \mathrm{~d}$ after administration (average $12.00 \mathrm{~d}$ of age); weaning, average $20.25 \mathrm{~d}$ of age.

${ }^{3}$ See text for more complete description of treatments. 
Table 5. Effect of fat-soluble vitamin administration by injection in early lactation and drinking water to pigs on plasma 25hydroxycholecalciferol $\left(25-\mathrm{OH} \mathrm{D}_{3}\right)$, retinol, and $\alpha$-tocopherol concentration (Exp. 3$)^{1}$

\begin{tabular}{|c|c|c|c|c|c|c|c|c|}
\hline \multirow{2}{*}{$\begin{array}{l}\text { Treatment at birth } \\
\text { Vitamins in water }\end{array}$} & \multicolumn{2}{|c|}{ Control } & \multicolumn{2}{|c|}{ Injection $\mathrm{A}, \mathrm{D}_{3}, \mathrm{E}$} & \multirow{2}{*}{ SEM } & \multicolumn{3}{|c|}{ p-values } \\
\hline & Without & With & Without & With & & Con vs Inj. & Water & Interaction \\
\hline No. of pigs & 6 & 7 & 6 & 5 & & & & \\
\hline \multicolumn{9}{|l|}{ 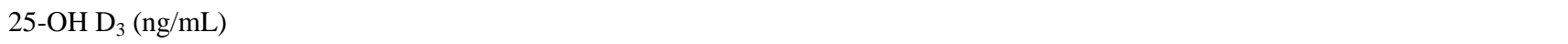 } \\
\hline At weaning & 6.07 & 4.11 & 43.55 & 37.17 & 2.96 & $<0.001$ & 0.10 & 0.36 \\
\hline d 14 postweaning & 33.57 & 65.91 & 38.95 & 68.08 & 2.67 & 0.27 & $<0.001$ & 0.43 \\
\hline Change $^{2}$ & 27.07 & 61.80 & -4.60 & 31.10 & 3.39 & $<0.001$ & $<0.001$ & 0.87 \\
\hline \multicolumn{9}{|l|}{ Retinol $(\mu \mathrm{g} / \mathrm{mL})$} \\
\hline At weaning & 0.24 & 0.13 & 0.18 & 0.15 & 0.04 & 0.68 & 0.15 & 0.37 \\
\hline d 14 postweaning & 0.31 & 0.22 & 0.29 & 0.22 & 0.03 & 0.71 & 0.01 & 0.75 \\
\hline Change $^{2}$ & 0.07 & 0.09 & 0.11 & 0.06 & 0.06 & 0.94 & 0.77 & 0.55 \\
\hline \multicolumn{9}{|l|}{$\alpha$-Tocopherol $(\mu \mathrm{g} / \mathrm{mL})$} \\
\hline At weaning & 4.28 & 4.78 & 6.28 & 8.22 & 0.67 & $<0.01$ & 0.11 & 0.31 \\
\hline d 14 postweaning & 0.87 & 2.87 & 1.72 & 3.05 & 0.24 & 0.07 & $<0.001$ & 0.17 \\
\hline Change $^{2}$ & -3.42 & -1.92 & -4.57 & -5.18 & 0.72 & 0.01 & 0.56 & 0.18 \\
\hline
\end{tabular}

SEM, standard error of the mean.

${ }^{1}$ Treatment: Control, Treatment 1 from Exp. 2; Inj. A, D 3 , E, Treatment 2 from Exp. 2; With, drinking water containing vitamin $\mathrm{D}_{3}(5,658$ IU/L) and E (95 IU/L) during $14 \mathrm{~d}$ after weaning; Without, no vitamin supplementation in drinking water.

${ }^{2}$ Change was calculated by subtracting values at weaning from values at $\mathrm{d} 14$ postweaning.

Table 5. The control and injection treatments from the nursing phase in Exp. 2 were used as the main treatment effects in the statistical analysis of Table 5. When pigs then received vitamins $D_{3}$ and $E$ via drinking water in the nursery, the pigs had higher plasma 25-OH $\mathrm{D}_{3}$ and $\alpha$-tocopherol concentrations at $\mathrm{d} 14$ postweaning $(\mathrm{p}<0.01)$. Additionally, the change of plasma $25-\mathrm{OH} \quad \mathrm{D}_{3}$ concentration from weaning to d 14 postweaning in pigs supplemented with vitamins via drinking water was also higher than pigs without water vitamin supplementation $(\mathrm{p}<0.01)$. In contrast, plasma retinol concentration was adversely affected at d 14 postweaning by high levels of vitamins $D_{3}$ and $\mathrm{E}$ in drinking water $(\mathrm{p}<0.05)$. Even though there was no difference on plasma 25-OH $\mathrm{D}_{3}$ concentration at $\mathrm{d} 14$ postweaning between the lactation treatments (control and injection), a lower change of plasma value was observed in the injection treatment that had higher plasma values at weaning compared with the control treatment $(p<0.01)$. In the case of plasma $\alpha$-tocopherol concentration, higher plasma values were observed in the injection treatment than the control treatment at weaning $(\mathrm{p}<0.01)$ and a trend at $\mathrm{d}$ 14 postweaning $(\mathrm{p}=0.07)$. The plasma values declined from weaning to $\mathrm{d} 14$ postweaning and a greater reduction was detected in the injection treatment $(\mathrm{p}<0.05)$.

In Exp. 4 (Table 6), a vitamin $\mathrm{D}_{3} / \mathrm{A} / \mathrm{E}$ injection to gestating sows increased absolute serum 25-OH $\mathrm{D}_{3}$ concentration at farrowing and its change from preadministration values $(p<0.01)$. Piglets from sows that received the prepartum vitamin $\mathrm{D}_{3}$ injection had higher serum $25-\mathrm{OH} \mathrm{D}_{3}$ concentrations than those in the control group at birth $(\mathrm{p}<0.01)$ and this improvement was maintained until weaning $(\mathrm{p}<0.05)$ but vitamin $\mathrm{D}_{3}$ injection to sows did not affect the change of serum $25-\mathrm{OH} \mathrm{D}_{3}$ concentration of piglets during suckling period.

\section{DISCUSSION}

This is the first study to investigate the plasma fatsoluble vitamin profiles of nursing piglets administered with fat-soluble vitamins by different administration routes.

Table 6. Effect of vitamin $\mathrm{D}_{3}$ injection to gestating sows on serum 25-hydroxycholecalciferol concentration of sows and piglets (Exp. 4) $)^{1,2}$

\begin{tabular}{lcccc}
\hline Criteria & Control & $\begin{array}{c}\text { Vitamin } \mathrm{D}_{3} \\
\text { injection }\end{array}$ & SEM & p-values \\
\hline Sows (ng/mL) & & & & \\
$\quad$ Initial & & & & \\
$\quad$ At farrowing & 43.07 & 37.10 & 2.61 & 0.19 \\
$\quad$ Change & & 58.60 & 2.86 & $<0.01$ \\
Piglets (ng/mL) & 1.03 & 21.50 & 3.19 & $<0.001$ \\
$\quad$ At birth & 4.00 & 6.15 & 0.36 & $<0.001$ \\
$\quad$ At weaning & 9.67 & 12.05 & 0.81 & 0.05 \\
Change $^{5}$ & 5.67 & 5.53 & 0.80 & 0.90 \\
\hline
\end{tabular}

SEM, standard error of the mean.

${ }^{1} 24$ sows were used $(n=11$ and 13 for control and injection treatments, respectively).

${ }^{2} 48$ piglets at birth $(n=22$ and 26 for control and injection treatments, respectively); 23 piglets at weaning and for change $(n=11$ and 12 for control and injection treatments, respectively).

${ }^{3}$ Before injection at $2 \mathrm{wk}$ prepartum.

${ }^{4}$ Change was calculated by subtracting values at initial from values at farrowing.

${ }^{5}$ Change was calculated by subtracting values at birth from values at weaning. 
In both Exp. 1 and 2, the results, collectively, demonstrate that the vitamin $\mathrm{D}_{3}$ status of pigs at weaning can be improved by administration of vitamin $D_{3}$ by a variety of methods and the results agree with those of recent studies (Rortvedt et al., 2012; Flohr et al., 2014a). However, plasma $25-\mathrm{OH} \mathrm{D}_{3}$ and $\alpha$-tocopherol concentrations declined from $10 \mathrm{~d}$ after administration to weaning in pigs from the injection and oral treatments, which agrees with Flohr et al. (2014a). This result suggests that plasma values are presumably diluted with the increase in blood volume associated with the rapid growth of the pigs as well as utilized by, or deposited in, various tissues. In contrast to Exp. 2, there was no decline in plasma $25-\mathrm{OH} \mathrm{D}_{3}$ level of control pigs in Exp. 1. Because of no vitamin administration to the control pigs, the control pigs illustrate the normal physiological response in the suckling period but the reason for the discrepancy between experiments is unclear. Therefore, further study is needed to verify these responses.

Plasma 25-OH $\mathrm{D}_{3}$ levels in sows increased from farrowing to weaning in both studies which may result from the feed intake change from the restricted feeding in gestation to ad libitum in lactation. Flohr et al. (2014b) reported sows fed gestation and lactation diets containing vitamin $\mathrm{D}_{3}$ had increased $25-\mathrm{OH} \mathrm{D}_{3}$ levels in plasma and milk by increasing supplementation levels from 1,500 to $6,000 \mathrm{IU}$ per $\mathrm{kg}$ diet at farrowing, $10 \mathrm{~d}$ of lactation and weaning but there were no day effect and interaction between treatment and day of lactation in milk $25-\mathrm{OH} \mathrm{D}_{3}$ levels. Therefore, this result indicates that, while plasma $25-\mathrm{OH} \mathrm{D}_{3}$ levels in sows can be increased from farrowing to weaning by absolute higher vitamin $\mathrm{D}_{3}$ intake in lactation than gestation, milk 25-OH $\mathrm{D}_{3}$ levels for the suckling piglet may be more difficult to increase. However, it should be noted from the current study that plasma values for control pigs were higher at $10 \mathrm{~d}$ after administration than at birth which demonstrates that milk clearly contributes to the vitamin D status of the pig.

Comparing the results between oral and injectable methods in the present experiments, it was demonstrated that the i.m. injection of vitamin $\mathrm{D}_{3}$, and $\mathrm{E}$ was able to enhance those statuses more than the oral administration. There have been few studies to compare the efficacy of different vitamin administration routes to pigs. In the case of sheep, ewes that received vitamin $\mathrm{D}_{3}$ by i.m. injection had higher plasma 25-OH $\mathrm{D}_{3}$ concentration and more lasting effects than those treated by oral administration (Hidiroglou et al., 1984). The parenteral administration of vitamin $\mathrm{D}_{3}$ does not require the process of intestinal absorption that oral administration of vitamin $\mathrm{D}_{3}$ requires. It has been documented that only $50 \%$ of orally administered vitamin D is absorbed (McDowell, 2000). Therefore, the process of intestinal absorption of vitamins probably affected the difference of plasma 25-OH $\mathrm{D}_{3}$ and $\alpha$ tocopherol concentration in this study. Regarding vitamin A status, there was no effect on plasma retinol concentration of piglets by vitamin A administration. When dogs were administered 10,000 IU of retinyl palmitate per $\mathrm{kg} \mathrm{BW}$ orally, plasma retinol concentration increased slightly to be maximized at $6 \mathrm{~h}$, and then declined to the baseline at $48 \mathrm{~h}$ (Raila et al., 2002). These results suggest that each fatsoluble vitamin may have different biological responses and effectiveness to enhance plasma vitamin profiles by types and administration routes.

There were no differences among treatments on BW and ADG of pigs during the suckling period in either experiment. These results again agree with some recent research (Flohr et al., 2014a). Rortvedt et al. (2012) also reported no improvement of ADG for $35 \mathrm{~d}$ after weaning in pigs administered a single oral mega-dose of vitamin $\mathrm{D}_{3}$ $(40,000 \mathrm{IU})$ at birth $(0.38 \mathrm{~kg} / \mathrm{d})$ compared with control pigs $(0.41 \mathrm{~kg} / \mathrm{d})$. In contrast, Tousignant et al. (2013) reported that in field conditions, pigs administered vitamin $\mathrm{D}_{3}$ (40,000 IU) orally at $2 \mathrm{~d}$ of age were heavier at weaning and $d 7$ postweaning than control pigs without vitamin $D_{3}$ administration but that the difference vanished at d 26 postweaning. The results of the current study indicated that there was no improvement in piglet growth by vitamin administration even though plasma levels of vitamins were clearly increased. This would seem to indicate that although some individuals may categorize normal plasma levels as "low", the levels are adequate for normal growth in an environment such as existed for the current research.

In Exp. 3, the water supplementation of vitamin $\mathrm{D}_{3}$ and E increased plasma 25-OH $\quad \mathrm{D}_{3}$ and $\alpha$-tocopherol concentrations which mean supplementation of vitamins via drinking water to nursery pigs is an effective method to enhance plasma status of vitamins. This result agreed with a previous study which reported the water supplementation of vitamin $\mathrm{D}_{3}$ to nursery pigs from weaning for $10 \mathrm{~d}$ elevated serum 25-OH $\mathrm{D}_{3}$ concentration on $\mathrm{d} 10$ postweaning (Flohr et al., 2014a). For vitamin E status, Wilburn et al. (2008) reported the water vitamin $\mathrm{E}$ supplementation increased plasma $\alpha$-tocopherol concentration of weanling pigs.

With regard to the changes of plasma $25-\mathrm{OH} \quad \mathrm{D}_{3}$ concentrations, the pigs in the lactation injection group that had higher plasma values at weaning had smaller increases of plasma $25-\mathrm{OH} \mathrm{D}_{3}$ concentrations at d 14 in response to the water supplementation compared with those in the control group that had lower values at weaning, resulting in no difference in absolute plasma values between the lactation treatments at d 14 postweaning. Trang et al. (1998) reported there is an inverse linear correlation between basal $25-\mathrm{OH} \mathrm{D}_{3}$ and the increase in $25-\mathrm{OH} \mathrm{D}_{3}$ for vitamin $\mathrm{D}_{3}$ treated humans. This result means that improvements from 
vitamin treatment at birth could vanish after weaning when pigs are switched from milk to feed. In the case of plasma $\alpha$-tocopherol concentration, the values declined after weaning regardless of treatment which is in line with the results from previous studies (Bonnette et al., 1990; Moreira and Mahan, 2002; Wilburn et al., 2008). On the other hand, even though a greater reduction of plasma values was observed in pigs from the injection group that had higher plasma values at weaning than those in the control group that had lower values, the pigs in the injection group still maintained higher plasma $\alpha$-tocopherol levels than those in the control group. In previous studies, plasma $\alpha$-tocopherol concentration declined steadily over $21 \mathrm{~d}$ after weaning when pigs were not supplemented with vitamin $\mathrm{E}$ (Moreira and Mahan, 2002; Wilburn et al., 2008). Plasma $\alpha$-tocopherol concentration in the current study was measured only at d 14 postweaning which does not allow determination if that decline would continue; thus, the effect of injection at birth seems to remain. However, because of limited data available in this study and lack of previous research, further study is needed to explain the changes in plasma $\alpha$-tocopherol concentration from weaning when pigs have different plasma levels at weaning.

In Exp. 4, a vitamin $D_{3}$ injection to gestating sows increased serum $25-\mathrm{OH} \mathrm{D} \mathrm{D}_{3}$ levels of sows at farrowing and of their offspring at birth. This result means the maternal vitamin D status affects the status of offspring at birth and it may result from the placental transportation which agrees with the observations of Goff et al. (1984) who reported that when sows received vitamin $D_{3}$ by i.m. injection at $d$ 20 prepartum, vitamin D status of their progeny was improved. Even though the difference in the serum $25-\mathrm{OH}$ $\mathrm{D}_{3}$ levels of piglets between treatments was maintained until weaning there was no difference in the magnitude of that treatment difference (or the change from birth to weaning) of $25-\mathrm{OH} \mathrm{D}_{3}$ concentration in serum of piglets which means the improvement of vitamin $\mathrm{D}_{3}$ status of gestating sows probably did not influence sow milk content. It may be noted that dietary vitamin D level was approximately 3 times higher in Exp. 4 than in Exp. 1 and 2, that the serum values of control sows at farrowing in Exp. 4 were approximately 2 times higher than those in Exp. 1 and 2 , and that weaning serum values of control piglets in Exp. 4 were double that of the values at birth and 55\% to $93 \%$ higher than the weaning values for control pigs in Exp. 1 and 2. Therefore, while milk may not be one of the best means of supplying vitamin $\mathrm{D}_{3}$, it either is adequate to increase serum values of piglets if sows are supplemented at levels above NRC (1998) recommendation or else the colostrum $\mathrm{D}_{3}$ concentration is elevated sufficiently from the sow dietary concentrations to allow the piglet serum values at weaning to be maintained at a higher level.

\section{IMPLICATIONS}

Vitamin $\mathrm{D}_{3}$ supplementation to newborn pigs can improve vitamin D status by increasing plasma $25-\mathrm{OH} \mathrm{D}_{3}$ concentrations regardless of administration routes. Vitamin A status of pigs was not affected by any of the means of administration whereas vitamin E status was affected by both routes of administration but more so by injection. Water supplementation of vitamin $\mathrm{D}_{3}$ and $\mathrm{E}$ to nursery pigs can enhance vitamin $\mathrm{D}$ and $\mathrm{E}$ status by increasing plasma 25-OH $\mathrm{D}_{3}$ and $\alpha$-tocopherol concentrations and initial vitamin status of pig plasma at weaning may not affect its plasma status at $14 \mathrm{~d}$ after weaning. The improvement of vitamin D status of pregnant sows can result in the enhancement of its status of their offspring. Several products and modes of administration exist to modify vitamin D status of piglets if that is a matter of concern for a swine operation. Further studies are needed, however, to determine if this altered vitamin D status has value in different production settings.

\section{ACKNOWLEDGMENTS}

This manuscript is based on research supported in part by the Kentucky Agricultural Experiment Station and is published by the Kentucky Agricultural Experiment Station as paper number 13-07-036. Appreciation is expressed to John Goihl (Agri-Nutrition Services, Inc., Shakopee MN, USA) for assistance with data collection in the sow experiment. Appreciation is also expressed to Akey Inc., Lewisburg, $\mathrm{OH}$ and to DSM Nutritional Products North America, Parsippany, NJ for routine ingredients used in the diets fed to the sows and pigs.

\section{REFERENCES}

Bonnette, E. D., E. T. Kornegay, M. D. Lindemann, and D. R. Notter. 1990. Influence of two supplemental vitamin E levels and weaning age on performance, humoral antibody production and serum cortisol levels of pigs. J. Anim. Sci. 68:1346-1353.

Federation of Animal Science Societies. 2010. Guide for the Care and Use of Agricultural Animals in Research and Teaching. 3rd edition. Federation of Animal Science Societies, Champaign, IL, USA.

Flohr, J. R., M. D. Tokach, S. S. Dritz, J. M. DeRouchey, R. D. Goodband, J. L. Nelssen, S. C. Henry, L. M. Tokach, M. L. Potter, J. P. Goff, N. J. Koszewski, R. L. Horst, E. L. Hansen, and E. D. Fruge. 2014a. Effects of supplemental vitamin $D_{3}$ on serum 25-hydroxycholecalciferol and growth of preweaning and nursery pigs. J. Anim. Sci. 92:152-163.

Flohr, J. R., M. D. Tokach, S. S. Dritz, J. M. DeRouchey, R. D. Goodband, J. L. Nelssen, and J. R. Bergstrom. 2014b. An evaluation of the effects of added vitamin $\mathrm{D}_{3}$ in maternal diets on sow and pig performance. J. Anim. Sci. 92:594-603. 
Goff, J. P., R. J. Horst, and E. T. Littledike. 1984. Effect of sow vitamin $\mathrm{D}$ status at parturition on the vitamin $\mathrm{D}$ status of neonatal piglets. J. Nutr. 114:163-169.

Håkansson, J., J. Hakkarainen, and N. Lundeheim. 2001. Variation in vitamin E, glutathione peroxidase and retinol concentrations in blood plasma of primiparous sows and their piglets, and in vitamin E, selenium and retinol contents in sows' milk. Acta Agric. Scand. Sect. A-Anim. Sci. 51:224-234.

Hidiroglou, M., C. J. Williams, and C. Shorrock. 1984. Vitamin $D_{3}$ response in sheep to oral versus parenteral administration and to intramuscular dose levels of vitamin $\mathrm{D}_{3}$. Can. J. Anim. Sci. 64:697-707.

Hill, G. M., J. E. Link, L. Meyer, and K. L. Fritsche. 1999. Effect of vitamin $\mathrm{E}$ and selenium on iron utilization in neonatal pigs. J. Anim. Sci. 77:1762-1768

Huang, Y., S. Henry, R. Friendship, K. Schwartz, and J. Harding. 2011. Clinical presentation, case definition, and diagnostic guidelines for porcine periweaning failure to thrive syndrome. J. Swine Health Prod. 19:340-344.

Lauridsen, C., U. Halekoh, T. Larsen, and S. K. Jensen. 2010 Reproductive performance and bone status markers of gilts and lactating sows supplemented with two different forms of vitamin D. J. Anim. Sci. 88:202-213.

Madson, D. M., S. M. Ensley, P. C. Gauger, K. J. Schwartz, G. W. Stevenson, V. L. Cooper, B. H. Janke, E. R. Burrough, J. P. Goff, and R. L. Horst. 2012. Rickets: case series and diagnostic review of hypovitaminosis D in swine. J. Vet. Diagn. Invest. 24:1137-1144.

McDowell, L. R. 2000. Vitamins in Animal and Human Nutrition. 2nd ed. Iowa State University Press, Ames, IA.
Moreira, I. and D. C. Mahan. 2002. Effect of dietary levels of vitamin E (all-rac-tocopheryl acetate) with or without added fat on weanling pig performance and tissue alpha-tocopherol concentration. J. Anim. Sci. 80:663-669.

National Research Council. 1998. Nutrient Requirements of Swine. 10th rev. ed. National Academy Press, Washington, DC, USA.

Raila, J., R. Radon, A. Trüpschuch, and F. J. Schweigert. 2002. Retinol and retinyl ester responses in the blood plasma and urine of dogs after a single oral dose of vitamin A. J. Nutr. 132:1673S-1675S.

Rortvedt, L. A., P. M. Cline, C. Ryer, B. Frederick, K. J. Retallick, D. K. Schneider, and T. D. Crenshaw. 2012. An oral dose of vitamin $\mathrm{D}$ at birth increased serum 25-OHD at weaning but failed to alter bone mineral density in pigs. J. Anim. Sci. 90(Suppl. 2):115(Abstr.).

Tousignant, S. J. P., S. C. Henry, A. Rovira, and R. B. Morrison. 2013. Effect of oral vitamin $D_{3}$ supplementation on growth and serum 25-hydroxy vitamin D levels of pigs up to 7 weeks of age. J. Swine Health Prod. 21:94-98.

Trang, H. M., D. E. C. Cole, L. A. Rubin, A. Pierratos, S. Siu, and R. Vieth. 1998. Evidence that vitamin $\mathrm{D}_{3}$ increases serum 25hydroxyvitamin $\mathrm{D}$ more efficiently than does vitamin $\mathrm{D}_{2}$. Am. J. Clin. Nutr. 68:854-858.

Wilburn, E. E., D. C. Mahan, D. A. Hill, T. E. Shipp, and H. Yang. 2008. An evaluation of natural (RRR- $\alpha$-tocopheryl acetate) and synthetic (all-rac- $\alpha$-tocopheryl acetate) vitamin $\mathrm{E}$ fortification in the diet or drinking water of weanling pigs. J. Anim. Sci. 86:584-591.

Witschi, A. K. M., A. Liesegan, S. Gebert, G. M. Weber. and C. Wenk. 2011. Effect of source and quantity of dietary vitamin D in maternal and creep diets on bone metabolism and growth in piglets. J. Anim. Sci. 89:1844-1852. 